\title{
ANALISIS KLASTER INDUSTRI ENTING GETI BERDASARKAN KINERJA UKM DAN KUALITAS PRODUK MENGGUNAKAN K-MEANS CLUSTERING
}

\section{Cluster Analysis of Enting Geti Sme's Based on SME's Perfomance and Product Quality Using K-Means Clustering}

\author{
Siti Asmaul Mustaniroh, Imam Santoso, Maria Theresia Yessi Krisma Permatasari \\ Jurusan Teknologi Industri Pertanian - Fakultas Teknologi Pertanian - Universitas Brawijaya \\ Jl. Veteran - Malang 65145 \\ *Penulis Korespondensi: email: theresiansayessy@yahoo.co.id
}

Disubmit: 28 Agustus 2018 Direvisi: 29 Januari 2019 Diterima: 23 Mei 2019

\begin{abstract}
ABSTRAK
Enting geti merupakan salah satu produk jajanan lokal khas Blitar yang terletak di Desa Rejowinangun, Kecamatan Kademangan. Pemerintah menjadikan Desa Rejowinangun sebagai salah satu desa wisata dengana konsep one village one product (OVOP) dan produk unggulan dari desa tersebut adalah enting geti. Sebagian besar dari UKM tersebut sudah memiliki kinerja dan kualitas produk yang baik akan tetapi, permasalahan yang terjadi pada UKM enting geti adalah belum adanya pembagian klaster atau pengelompokkan UKM untuk menetapkan jenis usaha dari masing-masing UKM, kurangnya asosiasi antar UKM, belum ada informasi dan penyuluhan terkait teknologi dan standar produk. Tujuan penelitian adalah menentukan pembagian klaster dari 6 UKM enting geti di Blitar untuk menentukan jenis usaha dari masing-masing UKM. Analisis pertama yang dilakukan adalah analisis klaster menggunakan metode K-means clustering yang didapatkan pembagian klaster sebanyak 2 klaster. Pembagian klaster didapatkan dari hasil perhitungan Sum of Square Error di metode Elbow. Hasil klaster 1 dan 2 dibedakan menjadi jenis usaha dimana klaster 1 masuk pada jenis usaha kecil dan klaster 2 masuk pada jenis usaha mikro. Pada klaster 1 memiliki 3 anggota UKM yaitu UKM Kuda Terbang, UKM Mas Puri dan UKM Rita Puri, sedangkan klaster 2 memiliki 3 anggota yaitu UKM Wina Puri, UKM Sumber Rejeki dan UKM Kapal Layar. Usulan perbaikan yang dapat diimplementasikan pada klaster 1 adalah perlu dibentuknya asosiasi dengan UKM yang lain dan pihak pemerintah, sedangkan pada klaster 2 perlu dibentuk kerja sama dengan pihak pemerintah untuk pengajuan nomor P-IRT, informasi pemasaran, modernisasi teknologi, SOP kerja, dan standar mutu produk
\end{abstract}

Kata kunci : Enting Geti; Klaster Industri; Kinerja UKM; Kualitas Produk

\begin{abstract}
Enting geti is one of traditional local snack located in Rejowinangun Village, Kademangan District, Blitar. The government made Rejowinangun Village one of the tourist villages and the concept of one village one product (OVOP) and become a special product. There are 15 SMEs but only 6 SMEs are still actively producing. Most of these UKMs have good performance and product quality, however, the problems are the absence of a cluster or grouping of SMEs to determine the type of business of each SME, lack of associations between SMEs, information and counseling related to technology and product standards. The purpose of this study is to determine the cluster distribution of 6 SMEs in Blitar to determine the type of business of each SME. The first analysis carried out was cluster analysis using K-means clustering method which obtained 2 clusters. Distribution of clusters is obtained from the calculation of Sum of Square Error in the Elbow method. Cluster 1 and 2 are differentiated into the types of businesses where cluster 1 is included in the type of small business and cluster 2 is in the type of micro business. Cluster 1 has 3 SME members are Kuda Terbang, Mas Puri and Rita Puri, while cluster 2 has 3 members are Wina Puri, Sumber Rejeki and Kapal Layar. Proposed improvements that can be implemented in cluster 1 are
\end{abstract}


Jurnal Teknologi Pertanian Vol. 20 No. 2 [Agustus 2019] 103-114

Analisis Klaster Industri Enting Geti [Permatasari dkk]

need to establish associations with other SMEs and the government, while in cluster 2 it is necessary to establish cooperation with the government to submit P-IRT numbers, marketing information, technology modernization, SOP work and product quality standards.

Keywords : Cluster Of Industry; Enting Geti; Product Quality; SME's Perfomance

\section{PENDAHULUAN}

Klaster industri merupakah suatu konsentrasi geografis dari beberapa perusahaan yang saling berhubungan pada suatu bidang tertentu. Menurut Carpinetti et al. (2008), klaster industri terdiri dari beberapa perusahaan yang didukung dengan adanya institusi-institusi lainnya seperti industri pendukung maupun lembaga pemerintah. Manfaat klaster industri yang diberikan dapat menciptakan peningkatan perekonomian dan daya saing, meningkatkan efektivitas dan produktivtas bagi perusahaan di dalam klaster serta peningkatan kemampuan inovasi yang melibatkan lembaga penelitian, meningkatkan efesiensi, dan mendorong diversifikasi produk dengan adanya inovasi (Sureephong et al., 2007). Secara umum, permasalahan yang dihadapi dalam pengembangan klaster industri adalah sifat produk yang pertanian yang mudah rusak dan bulky, bersifat musiman yang sangat dipengaruhi oleh kondisi iklim, kualitas produk, teknologi dan kinerja pihak perusahaan (Jain et al., 1999).

Enting geti merupakan sebuah produk atau jajanan khas Blitar yang terbuat dari bahan yang sederhana yaitu gula merah, kacang tanah, dan biji wijen. Produk ini diproduksi oleh UKM enting geti yang berada di Blitar yang memiliki lokasi pedesaan dekat dengan bahan baku dasar enting geti seperti kacang tanah dan gula merah. UKM enting geti merupakan salah satu sentra industri yang memproduksi jajanan lokal khas daerah Blitar yang berada di Kecamatan Kademangan, Desa Rejowinangun. Produk enting geti terbuat dari bahan baku yang sederhana seperti kacang tanah, dan gula merah. Menurut data dari Badan Pusat Statistika Kabupaten Blitar 2017, Kecamatan Kademangan memiliki jumlah perkebunan kacang tanah dan kelapa yang cukup besar yaitu 378 hektar untuk perkebunan kelapa dan 56 hektar untuk perkebunan kacang tanah. Jumlah UKM enting geti yang ada di Kecamatan Kademangan adalah 15 UKM. Akan tetapi, yang masih aktif memproduksi produk enting geti hanya 6 UKM saja, sementara 9 UKM lainnya hanya menerima produk jadi dari UKM lain dan dijual kembali. Keenam UKM tersebut adalah UKM Kuda Terbang, Wina Puri, Mas Puri, Sumber Rejeki, Kapal Layar, dan Rita Puri Asli. Sentra industri enting geti yang berada di Kecamatan Kademangan berada di daerah pedesaan yaitu desa Rejowinangun. Letak UKM sangat berdekatan sehingga pihak pemerintah memberikan inisiatif untuk membangun konsep One Village One Product (OVOP). Sehingga dengan adanya konsep tersebut, pemerintah menjadikan UKM enting geti yang ada di Desa Rejowinangun sebagai wisata dan pusat oleh-oleh jajanan khas Blitar. Kondisi saat ini yang terjadi pada UKM enting geti adalah belum adanya pembagian klaster atau pengelompokkan UKM untuk menetapkan jenis usaha dari masingmasing UKM, kurangnya asosiasi atau jalinan komunikasi antar UKM, belum adanya informasi dan penyuluhan terkait teknologi dan standar produk. Kondisi tersebut menjadi salah satu kendala yang dihadapi oleh pihak UKM dalam pengembangan industri yang sudah beroperasi selama puluhan tahun. Adanya pembagian klaster industri pada UKM enting geti diperlukan untuk mengetahui pembagian jenis usaha pada 6 UKM tersebut sehingga strategi pengembangan klaster industri padamasing-masing UKM yang berkaitan dapat dirancangan.

Analisis klaster industri yang digunakan adalah metode Elbow dan K-means Clustering. Kmeans clustering memiliki tujuan untuk mengetahui pembagian klaster sesuai dengan karakteristik UKM yang berkaitan (Hartigan dan Wong, 1979). Sebelum melakukan perhitungan menggunakan K-Means Clustering, pembagian klaster akan didapatkan dari hasil perhitungan Sum of Square Error di metode Elbow. Manfaat metode Elbow menurut Bholowalia dan $\mathrm{Ku}-$ mar (2014), berfungsi untuk mengetahui jumlah pembagian klaster dan cluster membership yang dianalisis. Analisis klaster menggunakan K-Means Clustering tidak akan lengkap tanpa adanya $t$-Test. Manfaat dari uji $t$ adalah untuk mengetahui apakah ada perbedaan yang signifikan di antara anggota klaster yang sudah terbentuk (Yang, 2012). 
Penelitian ini bertujuan untuk menentukan pembagian klaster pada 6 UKM enting geti dan menentukan jenis usaha dari masing-masing UKM, sehingga dapat memudahkan untuk memberikan pengarahan kepada para UKM terkait penyyuluhan, pemberian informasi dan perbaikan UKM.

\section{METODE}

Penelitian ini menggunakan pendekatan analisis klaster industri dengan mengelompokkan beberapa UKM enting geti yang ada di Blitar. Lokasi penelitian akan dilaksanakan di Kabupaten Blitar, Kecamatan Kademangan, Desa Rejowinangun dengan objek penelitian 6 UKM enting geti yang masih aktif memproduksi enting geti. Peneliti akan mengumpulkan data baik secara primer maupun sekunder melalui wawancara dan observasi bersama pihak UKM dan pihak Dinas. Penelitian ini merupakan penelitian deskripstif yang membutuhkan langkah-langkah penelitian sebagai berikut.

\section{Identifikasi Masalah}

Permasalahan yang terjadi pada UKM enting geti adalah belum adanya pembagian klaster atau pengelompokkan UKM untuk menetapkan jenis usaha dari masing-masing UKM, kurangnya asosiasi atau jalinan komunikasi antar UKM, belum adanya informasi dan penyuluhan terkait teknologi dan standar mutu produk.

\section{Tujuan Penelitian}

Tujuan penelitian ini adalah menentukan pembagian klaster dari 6 UKM enting geti di Blitar untuk menentukan jenis usaha dari masing-masing UKM dan menentukan impelemtasi manajerial yang dapat diterapkan UKM.

\section{Pengumpulan Data}

Data pertama yang digunakan adalah data yang berkaitan dengan kinerja UKM dan kualitas produk pada UKM. Kedua variabel yang diukur disajikan pada Tabel 1. Data yang didapatkan berasal dari hasil wawancara dan penyebaran kuesioner pada owner dan responden yang berjumlah 30 orang pada masing-masing UKM. Data tersebut digunakan untuk menilai kinerja UKM dan kualitas produk enting geti.

\section{Pengolahan Data}

Pengolahan data dilakukan dengan langkah-langkah seperti berikut.

1. Pengajuan data melalui kuesioner penilai kinerja UKM kepada pihak UKM sejumlah 6 UKM

2. Uji validitas dan reliabilitas kuesioner responden penilaian kualitas produk yang sudah diisi oleh 30 responden

3. Analisis pembagian klaster menggunakan metode Elbow dengan cara perhitungan Sum of Squaare Error

4. Analisis K-means clustering untuk mendapatkan nilai centroid/rata-rata

5. Uji t (t-Test) untuk mengetahui adanya perbedaan antara masing-masing klaster yang terbentuk.

Tabel 1. Variabel kinerja UKM dan kualitas roduk

\begin{tabular}{lll}
\hline No. & Variabel & Kriteria \\
\hline 1. & Kinerja UKM & 1. Lama Usaha \\
& 2. Bahan Baku (kg/bulan) \\
& 3. Pendapatan (Rp/bulan) \\
& 4. Tenaga Kerja (orang) \\
& 5. Investasi Awal (Rp) \\
& 6. Penjualan Produk (kg/bulan) \\
& 1. Performance (warna, aroma, rasa, bentuk, tekstur produk) \\
2. & 2. Durability (daya tahan, ketengikan produk) \\
& 3. Features (kemasan, harga produk) \\
& 4. Comformance to Specification (kesesuaian spesifikasi produk) \\
\hline
\end{tabular}


Jurnal Teknologi Pertanian Vol. 20 No. 2 [Agustus 2019] 103-114

Analisis Klaster Industri Enting Geti [Permatasari dkk]

Tabel 2. Karakteristik UKM enting geti

\begin{tabular}{|c|c|c|c|c|}
\hline No. & Keterangan & Minimum & Maksimum & Mean \\
\hline & KINERJA UKM & & & \\
\hline 1. & Lama Usaha (tahun) & 8 & 32 & 22 \\
\hline 2. & Bahan Baku (kg/bulan) & 500 & 3000 & 1533 \\
\hline 3. & Pendapatan (Rp/bulan) & 7.000 .000 & 5.000 .000 & 24.500 .000 \\
\hline 4. & Tenaga Kerja (orang) & 3 & 10 & 7 \\
\hline 5. & Investasi Awal (Rp) & 15.000 .000 & 70.000 .000 & 41.666 .666 \\
\hline \multirow[t]{2}{*}{6.} & Penjualan Produk (kg/bulan) & 200 & 1500 & 766 \\
\hline & KUALITAS PRODUK & & & \\
\hline 1. & Performance & 3,54 & 3,63 & 3,59 \\
\hline 2. & Durability & 3,55 & 3,78 & 3,69 \\
\hline 3. & Features & 3,53 & 4,39 & 3,87 \\
\hline 4. & Conformance to Specification & 3,64 & 3,90 & 3,78 \\
\hline
\end{tabular}

Sumber : Data diolah (2018)

Tabel 3. Hasil uji validitas

\begin{tabular}{lccc}
\hline Variabel & R-Hitung & R-Tabel & Keterangan \\
\hline Performance & 0,676 & 0,463 & Valid \\
Durability & 0,952 & 0,463 & Valid \\
Features & 0,916 & 0,463 & Valid \\
Conformance to Specification & 0,927 & 0,463 & Valid \\
\hline
\end{tabular}

Sumber : Data diolah (2018)

Tabel 4. Hasil uji reliabilitas

\begin{tabular}{lccc}
\hline Variabel & Cronbach Alpha & R-Tabel & Keterangan \\
\hline Performance & 0,710 & 0,60 & Reliabel \\
Durability & 0,888 & 0,60 & Reliabel \\
Features & 0,806 & 0,60 & Reliabel \\
Conformance to Specification & 0,827 & 0,60 & Reliabel \\
\hline
\end{tabular}

Sumber : Data diolah (2018)

Tabel 5. Perhitungan sum of square error

\begin{tabular}{ccc}
\hline Jumlah & Nilai SSE & Selisih \\
\hline 1 & 16.209 .660 & \\
2 & 8.758 .872 & 7.450 .788 \\
3 & 5.607 .147 & 3.151 .725 \\
4 & 3.236 .047 & 2.371 .100 \\
5 & 1.098 .371 & 2.137 .676 \\
\hline
\end{tabular}

Sumber : Data diolah (2018) 


\section{HASIL DAN PEMBAHASAN}

Pada tahap ini akan dibahas mengenai hasil pengolahan data yang sesuai dengan langkah analisis dan perhitungan.

\section{Karakteristik UKM Enting Geti}

Karakteristik UKM enting geti dapat dilihat pada Tabel 2. Karakteristik UKM enting geti dilihat dari hasil rata-rata/mean pada Tabel 2. Rata-rata lama usaha UKM enting geti di Kecamatan Kademangan adalah 22 tahun. Rata-rata bahan baku yang dibutuhkan adalah $1533 \mathrm{~kg} /$ bulan. Menurut Hidayat (2009), rata-rata pendapatan yang dihasilkan adalah sebesar Rp24.500.000,00. Jumlah tenaga kerja yang dimiliki oleh pihak UKM enting geti rata-rata ada 7 orang pekerja aktif. Menurut Ghobadian et al. (1994), hubungan antara pertumbuhan UKM dan produktivitas tenaga kerja perusahaan dapat berhubungan positif tergantung pada efek yang dimiliki terhadap pertumbuhan usaha. Investasi awal merupakan suatu aspek penanaman modal yang digunakan untuk proses produksi dalam meraih keuntungan suatu perusahaan. Rata-rata investasi UKM enting geti adalah sebesar Rp41.666.666,00. Penjualan produk 766 kg/bulan. Karakteristik UKM enting geti ini berdasarkan hasil analisis menggunakan software SPSS for Windows 17.

\section{Uji Validitas dan Reliabilitas}

Uji validitas dan reliabilitas digunakan untuk menguji kuesioner responden terkait kualitas produk yang dapat memberikan informasi kuesioner tersebut sudah valid dan reliabel atau belum. Hasil uji validitas kuesioner ditampilkan pada Tabel 3.

Hasil uji validitas menunjukkan nilai R-hitung > R-tabel. Menurut Mohajan (2017) faktor penentu valid atau tidaknya sebuah kuesioner dilihat dari nilai R-hitung harus lebih besar dari nilai R-tabel, sehingga dapat dikatakan kuesioner kualitas produk yang berdasarkan 4 dimensi kualitas tersebut sudah valid. Nilai R-tabel diperoleh dari rumus korelasi product moment yang diketahui jumlah responden 30 orang, nilai signifikasi $1 \%$ sebesar 0,463. Hal ini mengindikasikan bahwa seluruh pernyataan yang dibuat dinilai layak dan dapat digunakan untuk keperluan penelitian. Selanjutnya adalah uji reliabilitas yang dapat dilihat pada Tabel 4.

Berdasarkan dari hasil uji reliabel dapat ditunjukkan bahwa kuesioner kualitas produk berdasarkan 4 dimensi kualitas memiliki nilai cronbach alpha $\geq 0,60$. Menurut Bajpai dan Bajpai (2014), uji reliabilitas adalah serangkaian pengukuran atau serangkain alat ukur yang memiliki konsistensi bila pengukuran yang dilakukan dengan alat ukur itu dilakukan berulang. Suatu konstruktur atau variabel dikatakan reliabel, jika memiliki nilai alpha cronbach $\geq 0,60$ (Mohajan, 2017).

\section{Analisis Klaster}

Penelitian ini menggunakan analisis klaster non-hierarki dengan metode K-means clustering. Algoritma K-means clustering adalah algoritma yang dapat memecah data dalam klaster sehingga data yang memiliki keimiripan berada pada satu klaster yang sama dan data yang memiliki ketidaksamaan berada pada klaster yang lain (Carpinetti et al., 2008). Sebelum melakukan analisis klaster, perlu diketahui terlebih dahulu pembagian klasternya. Pembagian klaster akan dilakukan menggunakan metode Elbow dengan perhitungan niai Sum of Square Error. Perhitungan ini dilakukan menggunakan program R Studio. Hasil dari perhitungan Sum of Square Error dapat dilihat pada Tabel 5.

Tabel 6. Cluster membership

\begin{tabular}{cc}
\hline Nama UKM & Cluster Membership \\
\hline Kuda Terbang & 1 \\
Wina Putri & 2 \\
Mas Putri & 1 \\
Sumber Rejeki & 2 \\
Kapal Layar & 2 \\
Rita Puri Asli & 1 \\
\hline
\end{tabular}

Sumber: Data diolah (2018) 
Analisis klaster yang pertama dilakukan dengan menggunakan metode Elbow yang berfungsi untuk mendapatkan jumlah klaster berdasarkan iterasi yang dihasilkan. Nilai fungsi $k$ yang akan dibandingkan pada metode Elbow adalah dengan melihat nilai Sum of Square Error pada nilai klaster yang ditentukan (Bholowalia dan Kumar, 2014). Menurut Hartigan dan Wong (1979), metode Elbow memberikan ide atau gagasan dengan cara memilih nilai klaster dan kemudian menambah nilai klaster tersebut untuk dijadikan model data dalam penentuan klaster terbaik. Selain itu persentase perhitungan yang dihasilkan menjadi pembanding antara jumlah klaster yang ditambah. Hasil perhitungan Sum of Square Error dengan menggunakan metode Elbow didapatkan bahwa dengan melakukan clustering data $k=2$. Hasil Sum of Square Error dilakukan sampai percobaan 5 klaster. Klaster yang mengalami penurunan atau selisih yang cukup tinggi ada pada klaster 1 ke 2 yaitu 7450788. Setelah itu, dilakukan perhitungan nilai withim sum of square by cluster. Didapatkan hasil dari perhitungan nilai tersebut pada klaster 2, dibandingkan dengan jumlah selisih klaster ke-3 sampai ke-5 memiliki nilai selisih yang tidak terlalu jauh. Sebelum melakukan hasil pengujian K-means clustering, dapat dilakukan pengujian pembagian klaster menggunakan SPSS terlebih dahulu. Hasil dari perhitungan Elbow yang didapatkan dari nilai Sum of Square Error bahwa $k=2$ dapat diaplikasikan sebagai pengujian pada program SPSS. Hasil pembagian klaster SPSS dapat dilihat pada Tabel 6.

Berdasarkan hasil uji cluster membership yang dilakukan dengan menggunakan program SPSS tersebut dapat dilihat bahwa UKM Kuda Terbang, UKM Mas Puri dan UKM Rita Puri masuk pada klaster 1, sedangkan UKM Wina Puri, Sumber Rejeki, dan Kapal Layar masuk pada klaster 2 .

Setelah melakukan perhitungan cluster membership dapat melakukan perhitungan $\mathrm{K}$ means clustering berdasarkan klaster 1 dan 2 . Perhitungan ini bertujuan untuk melihat hasil

Tabel 7. Hasil pembagian klaster 1 dan 2 UKM enting geti

\begin{tabular}{|c|c|c|c|c|c|c|c|}
\hline \multirow[b]{2}{*}{ No. } & \multirow[b]{2}{*}{ Keterangan } & \multicolumn{3}{|c|}{ Klaster 1 (3 UKM) } & \multicolumn{3}{|c|}{ Klaster 2 (3 UKM) } \\
\hline & & $\begin{array}{l}\text { M i n i - } \\
\text { mum }\end{array}$ & $\begin{array}{l}\text { M a k s i - } \\
\text { mum }\end{array}$ & Mean & $\begin{array}{l}\text { M i n i - } \\
\text { mum }\end{array}$ & $\begin{array}{l}\text { M a k s i - } \\
\text { mum }\end{array}$ & Mean \\
\hline \multicolumn{8}{|c|}{ KINERJA UKM } \\
\hline 1 & $\begin{array}{l}\text { Lama Usaha } \\
\text { (tahun) }\end{array}$ & 20 & 32 & 24 & 8 & 26 & 19.75 \\
\hline 2 & $\begin{array}{l}\text { Bahan Baku } \\
\text { (kg/bulan) }\end{array}$ & 1500 & 3000 & 2333 & 500 & 900 & 733 \\
\hline 3 & $\begin{array}{l}\text { Pendapatan } \\
\text { (Rp/bulan) }\end{array}$ & 20.000 .000 & 50.000 .000 & 38.333 .333 & 7.000 .000 & 15.000 .000 & 10.666 .666 \\
\hline 4 & $\begin{array}{l}\text { Tenaga Kerja } \\
\text { (orang) }\end{array}$ & 10 & 10 & 10 & 3 & 3 & 3 \\
\hline 5 & $\begin{array}{l}\text { Investasi Awal } \\
\text { (Rp) }\end{array}$ & 45.000 .000 & 70.000 .000 & 56.333 .333 & 15.000 .000 & 35.000 .000 & 25.000 .000 \\
\hline 6 & $\begin{array}{l}\text { Penjualan } \\
\text { Produk } \\
\text { (kg/bulan) }\end{array}$ & 800 & 1500 & 1166 & 200 & 500 & 366 \\
\hline \multicolumn{8}{|c|}{ KUALITAS PRODUK } \\
\hline 1 & Performance & 3,61 & 3,63 & 3,61 & 3,54 & 3,60 & 3,57 \\
\hline 2 & Durability & 3,55 & 3,78 & 3,66 & 3,60 & 3,75 & 3,70 \\
\hline 3 & Features & 3,93 & 4,39 & 4,15 & 3,53 & 3,93 & 3,72 \\
\hline 4 & $\begin{array}{l}\text { Conformance to } \\
\text { Specification }\end{array}$ & 3,87 & 3,90 & 3,98 & 3,64 & 3,77 & 3,72 \\
\hline
\end{tabular}


rata-rata dari klaster 1 dan 2 serta menunjukkan perbedaan yang dihasilkan dan dapat dibandingkan antara klaster 1 dan klaster 2. Perhitungan K-means Clustering tetap menggunakan SPSS for Windows 17. Hasil rekap perhitungan K-means clustering pada klaster 1 dan klaster 2 menggunakan SPSS dapat dilihat pada Tabel 7 .

Hasil perhitungan K-means clustering menujukkan nilai rata-rata lama usaha pada klaster 1 yaitu 24 tahun, sedangkan klaster 2 yaitu 19,75 tahun. Klaster 1 memiliki lama usaha yang cukup lama mulai dari tahun 1986 hingga 1997, dibandingkan dengan klaster 2 yang didirikan mulai dari tahun 1992-2010. Menurut Huang (1998) lama usaha mengacu pada durasi usaha mulai dari awal sampai masih aktif produksi yang dapat meningkatkan pengalaman kinerja suatu industri. Menurut Aggarwal dan Aggarwal (2012), lama usaha menjadi penentu dan penilaian perkembangan dan pengetahuan yang sudah didapatkan pihak industri. Semakin lama umur usaha yang dimiliki maka semakin berpengalaman pula kinerja UKM yang didapat.

Rata-rata bahan baku pada klaster 1 sebesar $2333 \mathrm{~kg} /$ bulan, sedangkan pada klaster 2 sebesar $733 \mathrm{~kg} /$ bulan. Bahan baku pada klaster 1 cenderung lebih banyak yaitu sebesar 1500-3000 kg/bulan, dibandingkan klaster 2 sebesar 500-900 kg/bulan, dikarenakan adanya beberapa pengaruh seperti jumlah permintaan dan jumlah pendapatan. Jumlah permintaan pada klaster 1 lebih banyak dengan pendapatan yang sebanding, karena klaster 1 sudah memiliki tingkat pangsa pasar yang cukup luas seperti wilayah pemasaran yang terdapat baik di dalam kota, luar kota dan luar pulau dibandingkan klaster 2. Menurut Aggarwal dan Aggarwal (2012) bahan baku ditentukan dari aspek permintaan dan pendapatan. Semakin besar permintaan dan semakin besar pendapatan yang dihasilkan, maka bahan baku akan semakin besar pula. Menurut Kumar et al. (2010), pertimbangan dalam menentukan bahan baku tidak lepas juga dari tenaga kerja, mesin dan peralatan yang digunakan.

Rata-rata pendapatan yang dihasilkan oleh klaster 1 sebesar Rp38.333.333,00/ bulan, sedangkan pada klaster 2 adalah sebesar Rp10.666.666,00/bulan. Pendapatan yang dihasilkan klaster 1 lebih banyak dikarenakan adanya peningkatan penjualan produk dibandingkan pada klaster 2. Pen- jualan produk pada klaster 1 sudah banyak dipasarkan di berbagai daerah bahkan sampai luar pulau dan mini market, sehingga dapat menunjang tingkat penjualan dan pendapatan yang dihasilkan. Menurut Bonu dan Motau (2009) pendapatan dari suatu industri dipengaruhi dari hasil penjualan produk dan jumlah permintaan konsumen.

Semakin besar jumlah permintaan pasar, maka semakin besar pendapatan yang dihasilkan, sedangkan Menurut Cooper (1984), pendapatan dari suatu usaha dihasilkan jika perbandingan antara kinerja baik dari produksi dan pemasaran tersebut seimbang, maka menghasilkan pendapatan yang seimbang. Selain itu, harga jual pun menjadi pertimbangan karena konsumen lebih menyukai harga yang lebih terjangkau sesuai dengan kualitas produk yang dihasilkan.

Rata-rata jumlah tenaga kerja pada klaster 1 sebanyak 10 orang, sedangkan pada klaster 2 sebanyak 3 orang. Masing-masing UKM enting geti memperkerjakan warga yang berada di desa tersebut dan pihak keluarga sendiri. Klaster 1 memiliki jumlah tenaga kerja yang lebih banyak yaitu 10 orang karena bahan baku yang ditentukan selama produksi dan permintaan konsumen, sedangkan tenaga kerja pada klaster 2 ratarata memiliki 3 tenaga kerja. Jumlah tenaga kerja pada UKM enting geti disesuaikan oleh bahan baku dan kemampuan pihak UKM untuk memperkerjakan dengan pendapatan yang didapatkan. Menurut Doepke dan Zilibotti (2009), tenaga kerja merupakan aspek penting sebagai penentu keberhasilan suatu produksi dan usaha, karena tenaga kerja berfungsi untuk menjadi operator pelaksana proses produksi. Kualifikasi tenaga kerja yang baik menurut Lubis (2014) adalah keterampilan kerja yang ulet, pengetahun dan pengalaman dalam melakukan suatu proses produksi. Selain itu, pihak UKM dapat bekerja sama kepada pihak pemerintah untuk memberikan penyuluhan yang tepat di dalam proses produksi maupun kinerja UKM secara keseluruhan, misal adanya penyuluhan dari Dinas Perdagangan dan Perindustrian (DISPERINDAG) dan Dinas Pertanian.

Rata-rata investasi awal klaster 1 sebesar Rp 56.333.333, sedangkan klaster 2 sebesar Rp 25.000.000. Investasi awal tersebut digunakan oleh pihak UKM untuk membangun perusahaan didapatkan dari sumber pinjaman serta sumber dari pihak UKM 
sendiri. Beberapa pihak UKM dari klaster 1 maupun klaster 2 mendapatkan modal atau investasi awal dari penyedia pinjaman yaitu bank. Pihak UKM meminjam modal kepada bank untuk menjadikan usaha tersebut berkembang dan ada pula yang mendapatkan investasi awal dengan modal sendiri. Dilihat dari banyaknya investasi awal yang dikeluarkan, kedua klaster ini memiliki jenis usaha yang berbeda yaitu usaha mikro dan usaha kecil. Klaster 1 termasuk pada jenis usaha kecil dikarenakan usaha ini memiliki kekayaan bersih lebih dari Rp50.000.000,00. Menurut Susanto et al. (2017), kriteria usaha kecil memiliki kekayaan memiliki kekayaan bersih lebih dari Rp50.000.000,00 sampai dengan Rp500.000.000,00 (tidak termasuk tanah dan bangunan tempat usaha) atau memiliki hasil penjualan tahunan lebih dari Rp300.000.000,00 sampai dengan paling banyak Rp2.500.000.000,00. dilihat dari hasil pendapatan kedua UKM tersebut, rata-rata pendapatannya sejumlah Rp65.000.000,00 yang jika diakumulasikan dalam tahun mencapai Rp780.000.000,00/tahun. Klaster 2 memiliki jenis usaha mikro karena menurut Butarbutar et al. (2017), jenis usaha mikro memiliki kekayaan bersih paling banyak Rp50.000.000,00 (tidak termasuk tanah dan bangunan tempat usaha) atau memiliki hasil penjualan tahunan paling banyak Rp300.000.000,00.

Nilai rata-rata penjualan produk klaster 1 per bulan mencapai 1166 kg/bulan, sedangkan pada klaster 2 mencapai 366 $\mathrm{kg}$ /bulan. Penjualan produk pada kedua klaster tergantung jumlah permintaan konsumen. Klaster 1 memiliki penjualan produk yang cukup besar dikarenakan tingkat permintaan yang lebih banyak dengan pangsa pasar yang luas dibandingkan klaster 2. Ada beberapa faktor untuk meningkatkan penjualan produk adalah dengan memberikan harga jual yang terjangkau, pelayanan yang baik dan dilakukan evaluasi secara rutin oleh pihak UKM (Shibao dan Keyun, 2007). Konsumen lebih menyukai produk dengan harga jual yang terjangkau dan kualitas produk yang sesuai. Menurut Fahim et al. (2006), penjualan produk dapat ditingkatkan melalui adanya promosi dan inovasi baru dari pihak industri yang bertujuan agar konsumen tidak merasa bosan dengan produk yang disajikan.

Rata-rata aspek perfomance produk enting geti klaster 1 adalah 3,61, sedangkan pada klaster 2 yaitu 3,57. Aspek perfomance enting geti dinilai dari warna, aroma, rasa, bentuk dan tekstur produk. Penilaian produk berdasarkan perfomance pada klaster 1 dan 2 bahwa produk sudah cukup sesuai dengan keinginan konsumen. Pada umumnya, enting geti memiliki warna cokelat tua yang berasal campuran dari kacang tanah dan gula merah, memiliki aroma harus, rasa yang manis dan gurih, bentuk kotak atau bulat dan tekstur yang keras. Produk enting geti klaster 1 dan memiliki kriteria yang sama akan tetapi ada beberapa UKM yang hanya menyediakan variasi bentuk kotak. Menurut Meal et al. (2007), perfomance dari suatu produk dapat dinilai dari bentuk fisik yang unik dan kreatif. Hal tersebut dapat menarik konsumen untuk membeli produk dan menjadi daya tarik tersendiri bagi konsumen karena secara fisik, konsumen akan menilai produk tersebut sudah memuaskan atau belum. Menurut Yoon dan Lilien (1985), perfomance berkaitan dengan aspek fungsional dari produk dan merupakan karakteristik utama yang dipertimbangkan konsumen ketika ingin membeli suatu produk. Fungsi dari produk contohnya produk makanan, dapat dilihat secara fisik dan organoleptik untuk menarik kepuasan konsumen. semakin baik perfoma yang diciptakan produk tersebut makan konsumen akan semakin tertarik untuk membelinya.

Rata-rata aspek durability pada klaster 1 adalah 3,66, sedangkan pada klaster 2 adalah 3,70. Nilai pada klaster 1 dan 2 tidak memiliki selisih yang jauh, sehingga nilai ketahanan produk enting geti baik klaster 1 dan 2 sudah sesuai keinginan konsumen. Aspek durability pada produk enting geti dinilai dari masa berlaku produk dan tingkat ketahanan produk terhadap ketengikan. Produk enting geti yang dimiliki oleh klaster 1 dan 2 memiliki daya tahan produk yang cukup lama yaitu mulai dari 3 bulan sampai 1 tahun. Menurut Fahim et al. (2006) daya tahan dari suatu produk dapat dilihat pada masa berlaku yang bersifat lama atau tidak lama. Menurut Nilasari dan Istiatin (2015), konsumen lebih menyukai produk yang memiliki daya tahan lama agar dapat dikonsumsi kapan saja. Tingkat ketengikan adalah seberapa tengik produk yang dihasilkan mengingat bahan baku enting geti yang cepat sekali rusak. Menurut Bertin et al. (2010), produk yang baik berasal dari bahan baku yang baik juga. Salah satu aspek yang menjadikan bahan baku dapat dinilai baik adalah bahan baku yang memenuhi kriteria 
dan cara bahan baku diperlakukan sebelum diolah, seperti cara penyimpanan dan pemilihan bahan.

Rata-rata aspek features pada klaster 1 adalah 4,15, sedangkan pada klaster 2 adalah 3,72 . Hal ini menunjukkan bahwa konsumen memberi pernyataan bahwa fitur yang diberikan produk enting geti pada klaster 1 sudah sesuai dan pada klaster 2 cukup sesuai. Features dapat dilihat dari segi kemasan produk dan kesesuaian produk tidak mengandung minyak. Fitur yang disajikan oleh klaster 1 sudah sesuai karena cara penyajian produk dalam kemasan sudah bersifat informatif, terdiri dari label kemasan yang memberikan informasi nama atau merk, bahan baku, masa berlaku, cara penyimpanan, dan nama industri yang mengolah, sedangkan pada klaster 2 bersifat kurang informatif dan hanya mencantumkan merk produk dan bahan baku yang digunakan. Kemasan yang dipakai kedua klaster adalah kemasan plasti polypropylene, dimana kemasan ini adalah kemasan plastik yang tidak mudah bocor dan tidak mudah robek. Kesesuaian produk dinilai dari produk yang diberikan tidak mengandung minyak berlebih, sehingga produk tidak mudah rusak dan tengik. Klaster 1 dan 2 memiliki produk enting geti yang sesuai dan tidak mengandung minyak berlebih baik pada produk maupun kemasan. Menurut Griffiths et al. (2008) features adalah aspek penunjang suatu produk seperti kemasan dan harga yang diberikan. Kemasan yang baik adalah kemasan yang memiliki informasi lengkap. Menurut Bertin et al. (2010), untuk meningkatkan kualitas fitur produk dapat dengan cara inovasi produk melalui pembaharuan bentuk dan kemasan, evaluasi kesesuaian produk yang dihasilkan dan memberikan informasi yang lengkap pada kemasan.

Rata-rata aspek conformance to specification produk enting geti klaster 1 adalah 3,98, sedangkan klaster 2 adalah 3,72. Aspek conformance to specification dinilai berdasarkan pada spesifikasi dan komposisi produk yang sesuai dengan keinginan konsumen. Klaster 1 memiliki nilai yang tidak jauh berbeda dengan penilaian yang didapatkan oleh klaster 2 sehingga produk pada klaster 1 sudah memenuhi kriteria dan sesuai dengan spesifikasi yang ditentukan. Aspek tersebut juga dapat dilihat dari seberapa besar cacat produk yang dihasilkan dan diterima oleh konsumen. Spesifikasi dan komposisi produk enting geti pada umumnya berupa karakteristik sebagai makanan ringan yang dapat di akses oleh semua kalangan konsumen, berupa produk makanan dengan harga terjangkau dan awet serta komposisi yang sesuai. Menurut Baresa et al. (2016), conformance to specification dapat dilihat dari karakteristik dasar sebuah produk apakah produk tersebut sudah memenuhi spesifikasi yang diinginkan konsumen atau belum. Menurut Tenner dan Detoro (1992), untuk meningkatkan conformance to specification khususnya pada produk makanan adalah dengan cara pemberian tester kepada konsumen sehingga konsumen dapat menilai dan memberikan pendapat tentang produk tersebut.

Analisis selanjutnya adalah analisis uji t yang digunakan untuk mengetahui perbedaan antara 2 klaster. Hasil analisis ttest dapat dilihat di Tabel 8 yang terdiri dari aspek kinerja UKM mulai dari lama usaha, bahan baku, pendapatan, tenaga kerja, investasi awal dan penjualan produk. Tabel 8 menunjukkan hasil uji Shapiro Wilk dan Lilliefors. Nilai $p$-value (Sig) menunjukkan adanya perbedaan yang signifikan pada kedua klaster. P-value uji Shapiro wilk menunjukkan nilai sig pada kedua klaster sama-sama berdistribusi normal. Hasil analisis t-test pada aspek kualitas produk klaster 1 dan 2 yang mencakup perfomance, durability, features, dan conformance to specification dapat dilihat pada nilai $p$-value (Sig) Lilliefors menunjukkan adanya perbedaan yang signifikan. P-value uji Shapiro wilk menunjukkan kedua kelompok sama-sama berdistribusi normal karna memiliki nilai Sig 0,00. Menurut Yin et al. (2010), t-test berfungsi untuk melihat perbedaan antara beberapa kelompok dilihat dari 2 uji yang berbeda yaitu uji Shapiro Wilk dan Lilliefors. Menurut Evans (2008), uji Lilliefors adalah pengujian yang melihat sebesar signifikasi perbedaan antara kelompok 1 dengan kelompok lainnya dilihat dari nilai $p$-value lebih kecil atau lebih besar dari 0,05. Jika nilai lebih kecil maka terjadi perbedaan yang signifikan, jika nilai lebih besar maka tidak terjadi perbedaan antar kelompok. Uji Shapiro Wilk digunakan untuk mengetahui normalisasi dalam independent $t$-test. Jika nilai $p$-values (Sig) lebih dari 0,05 maka nilai tersebut normal.

\section{Perbedaan antara Klaster 1 dan Klaster 2}

Berdasarkan hasil pengelompokkan 6 UKM melalui analisis klaster, didapatkan 
beberapa perbedaan antara klaster 1 dan 2 yaitu:

1. Klaster 1 terdiri dari 3 UKM yaitu UKM Kuda Terbang, UKM Mas Puri, dan UKM Rita Puri Asli, memiliki tingkat kinerja UKM (lama usaha, bahan baku, pendapatan, investasi awal, tenaga kerja, dan penjualan produk) yang lebih baik. Begitu pula dengan kualitas produk (perfomance, durability, features, dan conformance to specification) yang baik. Kinerja UKM dan kualitas produk pada klaster 1 jauh lebih maju karena pengalaman dan produk yang sudah tersebar luas hingga luar pulau. Klaster 2 terdiri dari 3 UKM yaitu UKM Wina Puri, UKM Sumber Rejeki dan UKM Kapal Layar, memiliki tingkat kinerja UKM (lama usaha, bahan baku, pendapatan, investasi awal, tenaga kerja, dan penjualan produk) dengan penilaian yang kurang memuaskan dan tidak sebagus UKM klaster 1. Begitu pula dengan kualitas produk (perfomance, $d u-$ rability, features, dan conformance to specification) yang masih kurang memuaskan.

2. UKM klaster 1 memiliki jenis usaha kecil karena memiliki kekayaan memiliki kekayaan bersih lebih dari Rp50.000.000,00 sampai dengan Rp500.000.000,00 (tidak termasuk tanah dan bangunan tempat usaha) atau memiliki hasil penjualan tahunan lebih dari Rp300.000.000,00 sampai dengan paling banyak Rp2.500.000.000,00 UKM klaster 2 memiliki jenis usaha mikro karena jenis usaha mikro memiliki kekayaan bersih paling banyak Rp50.000.000,00 (tidak termasuk tanah dan bangunan tempat usaha) atau memiliki hasil penjualan tahunan paling banyak Rp300.000.000,00.

3. Standar produk yang dimiliki oleh UKM klaster 1 sampai saat ini hanya memiliki nomor P-IRT. Pengendalian mutu pada UKM klaster 1 mulai dilakukan namun tidak secara berkala karena keterbatasan ilmu dan pengetahuan dari pihak UKM.

UKM klaster 2 sampai saat ini belum memiliki standar yang resmi, hanya pada UKM Mas Puri saja yang sudah memiliki nomor P-IRT. Beberapa UKM lainnya belum memiliki standar resmi karena keterbatasan dana, pengetahuan dan mutu produk yang dihasilkan.

\section{Implementasi Manajerial Pada Klaster 1 dan Klaster 2}

Berdasarkan dari hasil perhitungan analisis klaster yang didapatkan 2 kelompok UKM yaitu klaster 1 dan 2 memiliki jenis usaha yang berbeda dengan kekurangan dan kelebihan yang berbeda.

1. Implementasi Manajerial Klaster 1

Klaster 1 terdiri dari 3 UKM yaitu UKM Kudat Terbang, UKM Mas Puri, dan UKM Rita Puri dengan jenis usaha kecil. UKM tersebut memiliki kinerja UKM dan kualitas produk yang jauh lebih baik daripada klaster 2 karena dari segi produk, sudah dipasarkan secara luas secara lokal, luar jawa hingga mini market. Akan tetapi masih belum adanya asosiasi atau kerja sama antar UKM. Pihak UKM dapat berkontribusi untuk mendapatkan informasi lebih yang bekerjasama antar UKM dan pihak pemerintah. Asosiasi UKM sangat berguna untuk menjaring ilmu dan informasi terlebih dalam hal modernisasi teknologi (mesin dan peralatan). Selain itu adanya evaluasi berkala dari pihak UKM untuk mempertahankan kinerja UKM yang bagus dengan penerapan SOP kerja maupun standar kerja.

2. Implementasi Manajerial Klaster 1 Klaster 2 terdiri dari 3 UKM yaitu UKM Wina Puri, UKM Sumber Rejeki dan UKM Kapal Layar yang memiliki jenis usaha mikro. UKM tersebut termasuk pada golongam usaha yang masih baru berdiri. Kinerja UKM pada klaster 2 masih cukup kurang dan pemasaran produk yang masih dipasarkan secara lokal saja. Kualitas produk yang masih belum ada dan masih belum memiliki nomor P-IRT. Pihak UKM dapat bekerjasama dengan pihak UKM lainnya untuk bertukar informasi dan membangun asosiasi yang dibawahi oleh pihak pemerintah yang berfungsi untuk memberikan penyuluhan terkait pengetahuan mengenai teknologi sampai produk. Pihak UKM dapat disarankan untuk pengajuan nomor P-IRT bersama pihak pemerintah, perbaikan teknologi (mesin dan peralatan) yang masih tradisional dan memperbaiki kinerja UKM dengan cara penerapan SOP kerja dan standar produk. 


\section{SIMPULAN}

Penentuan klaster UKM enting geti dibagi menjadi 2 klaster yaitu klaster 1 dan klaster 2. Klaster 1 terdiri dari UKM Kuda Terbang dan UKM Rita Puri, sementara pada klaster 2 terdiri dari UKM Mas Puri, Wina Puri, Sumber Rejeki, dan Kapal Layar. Klaster 1 termasuk pada jenis usaha kecil sedangkan klaster 2 termasuk pada jenis usaha mikro. Klaster 1 memiliki kondisi kinerja UKM dan kualitas produk yang lebih bagus daripada klaster 2. Secara garis besar, klaster 1 memiliki kinerja UKM yang dinilai sudah sesuai karena kinerja UKM pada klaster 1 lebih maju dan baik daripada klaster 2. Kulitas produk yang dihasilkan oleh klaster 1 pun sudah sesuai menurut 4 kriteria dimensi kualitas yang juga sudah memiliki standar nomor P-IRT dibandingkan kualitas produk klaster 2. Oleh karena itu perlu adanya asosiasi dan bantuan kerja sama dari pihak pemerintah untuk memberikan penyuluhan dan informasi kepada pihak UKM terkait kinerja UKM dan kualitas produk.

\section{DAFTAR PUSTAKA}

Aggarwal, -N., Aggarwal, -K., 2015. A midpoint based k-means clustering algorithm International. Journal on Computer Science and Engineering (IJCSE). 4(6), 11-30. http://citeseerx.ist.psu.edu/ viewdoc/download?doi=10.1.1.447.55 $71 \&$ rep $=$ rep $1 \&$ type $=$ pdf

Ariani, Utomo, M, -N., 2017. Kajian strategi pengembangan usaha mikro kecil dan menengah (UMKM) di kota tarakan. Jurnal Organisasi dan Manajemen. 13(2), 99118. http://jurnal.ut.ac.id/index.php/ JOM/article/download/432/365/

Badan Pusat Statistika Kabupaten Blitar. 2017. Luas Panen, Produksi dan Rata-Rata Produksi Kacang Tanah menurut Kecamatan, 2012-2016. Dilihat 20 Desember 2017. https:/ / blitarkota.bps.go.id/ dynamictable / 2018/04/18/34/76-luas-panen-produksi-dan-rata-rata-produksi-kacang-tanah-menurut-kecamatan-2012-2016-.html

Bajpai, S, -R., Bajpai, -R.,. 2014. Goodness of measurement: reliability and validity. International Journal of Medical Science and Public Health. 3(2), 112-115. https:/ / doi. org/ 10.5455/ijmsph.2013.191120133
Baresa, -S., Bogdan, -S., Ivanovic, -Z., 2016. Capital investments and financial profitability. UTMS Journal of Economics. 7(1), 49-59. https://pdfs.semanticscholar.org/e2b2/0a3e8bd4f2 dadf2895ddf131d79480f12db0.pdf?_ ga=2.122295371.173931887.1562553849853231197.1557129431

Bertin, -M., Atanassova, -I., Gingras, -Y., Lariviere, - V., 2010. The invariant distribution of references in scientific papers. Journal of the Association for Information Science and Technology. 67(1), 67-85. https://doi.org/10.1002/asi.23367

Bholowalia, -P., Kumar, -A.,. 2014. EBKmeans: a clustering technique based on elbow method and k-means in WSN. International Journal of Computer Applications. 105(9), 17-24. https:/ / doi. org/10.5120/18405-9674

Bonu, N, -S., Motau, -P., 2009. The impact of income tax rates (ITR) on the economic development of Botswana. Journal of Accounting and Taxation. 1(1), 008-022. http://ubrisa.ub.bw/ bitstream/handle/10311/1085/ Bonu \%20and\%20Motau_JAT_2009. pdf?sequence $=1$ \&isAllowed $=\mathrm{y}$

Butarbutar, G, -R., Widayatsari, -A., Aqualdo, -N., 2017. Analisis faktor-faktor yang mempengaruhi pendapatan usaha industri makanan khas di kota tebing tinggi. JOM Fekon. 4(1), 619-633. https://jom.unri.ac.id/index.php/JOMFEKON/article/view/12776

Carpinetti, L, C, -R., Galdámez, E, V, -C., Gerolamo, M, -C., 2008. A measurement system for managing performance of industrial clusters. International Journal of Productivity and Performance Management. 57(5), 405-419. https://doi. org/10.1108/17410400810881854

Cooper, R, -G., 1984. New product strategies: what distinguishes the top performers?. Journal of Product Innovation Management. 1(3), 151-164. https://doi. org/10.1016/S0737-6782(84)80012-0

Doepke, -M., Zilibotti, -F., 2009. International Labor Standards And The Political Economy Of Child-Labor Regulation. Journal of the European Economic Association. 7(1), 508-518. https://doi. org/10.1162/JEEA.2009.7.2-3.508

Evans, JR., 2008. Operative Management Quality Performance and Values. West publishing, New York, USA 
Jurnal Teknologi Pertanian Vol. 20 No. 2 [Agustus 2019] 103-114

Analisis Klaster Industri Enting Geti [Permatasari dkk]

Fahim, A, -M., Salem, A, -M., Torkey, F, -A., Ramadan, M, -A., 2006. An efficient enhanced $k$-means clustering algorithm. J. Zhejiang. Univ. SCIENCE. A. 7(10), 1626-1633. https://doi.org/10.1631/ jzus.2006.A1626

Ghobadian, -A., Speller, -S., Jones, -M., 1994. Service quality: concepts and models. International Journal of Quality $\mathcal{E}$ Reliability Management. 11(9), 43-66. https:/ / doi.org/10.1108/02656719410074297

Griffiths, T, -L., Steyvers, -M., Blei, D, -M., and Tenenbaum, J, -B., 2008. Integrating topics and syntax. Advances in Neural Information Processing Systems. 4(3), 193-208. http://psiexp.ss.uci.edu/research/papers/composite.pdf

Hartigan, J, -A., Wong, M, -A., 1979. Algorithm as 136: a $k$-means clustering algorithm. Journal of the Royal Statistical Society. 28(1), 100-108. https://doi. org/100-108. 10.2307/2346830

Hidayat, -R., 2009. Pengaruh kualitas layanan, kualitas produk dan nilai nasabah Terhadap kepuasan dan loyalitas nasabah bank mandiri. Jurnal Manajemen dan Kewirausahaan. 11(1), 59-72. https:// doi.org/10.9744/jmk.11.1.pp.\%2059-72

Huang, -Z., 1998. Extensions to the kMeans algorithm for clustering large data sets with categorical values. Data Mining and Knowledge Discovery. 2(1), 283-304. https://doi. org/10.1023/A:1009769707641

Jain, A, -K., Murty, M,, -N., Flynn, P, -J., 1999. Data clustering: a review. ACM Computing Surveys. 31(3), 265-323. http:// dx.doi.org/10.1145/331499.331504

Kumar, -R., Puran, -R., Dhar, -J., 2010. Enhanced k-means clustering algorithm using red black tree and min-heap. International Journal of Innovation, Management and Technology. 2(1), 1-25. http:// www.ijimt.org/papers/102-M480.pdf

Lubis, C, A, B, -E., 2014. Pengaruh jumlah tenaga kerja, tingkat pendidikan pekerja dan pengeluaran pendidikan terhadap pertumbuhan ekonomi. Jurnal Economia. 10(2), 187-193. http:/ / dx.doi. org/10.21831/economia.v10i2.7544

Meal,H,-C., Wachter, M,-H., Whybark, D, -C., 2007. Material requirements planning in hierarchical production planning systems. International Journal of Production Research. 25(7), 355-458. https:// doi.org/10.1080/00207548708919887
Mohajan, -H.,. 2017. Two criteria for good measurements in research: validity and reliability. Annals of Spiru Haret University Economics Series. 17(3), 97108. https://papers.ssrn.com/sol3/ papers.cfm?abstract_id=3152355

Nilasari, -E., Istiatin., 2015. Pengaruh kualitas pelayanan terhadap kepuasan konsumen pada dealer pt. ramayana motor sukoharjo. Jurnal Paradigma. 13(1), 0520. https://media.neliti.com/media/ publications/115736-ID-pengaruhkualitas-pelayanan-terhadap-kep.pdf

Shibao, -S., Keyun, -Q., 2007. Research on modified k-means data cluster algorithm. Computer Engineering. 33(13), 5-25. http://en.cnki.com.cn/Article_ en/CJFDTOTAL-JSJC200713068.htm

Sureephong, -P., Chakpitak, -N., Ouzrout, -Y., Neubert, -G., Bouras, -A., 2007. Knowledge management system architecture for the industry cluster. The International Conference on Industrial Engineering and Engineering Management (IEEM 2007). htpps://doi. org/10.1109/IEEM.2007.4419536

Susanto, D, -A., Isharyadi,-F., Aliyah,-N., 2016. Faktor-faktor yang mempengaruhi usaha kecil menengah dalam menerapkan standar secara konsisten. Jurnal Standardisasi. 18(2), 129-138. http://dx.doi. org/10.31153/js.v18i2.705

Tenner, AR., Detoro, IJ. 2010. Total Quality Management: Three Steps to Continuous Improvement. Addison - Wesley

Yang, -Y., 2012. The research of imbalanced data set of sample sampling method based on k-means cluster and genetic algorithm. Energy Procedia. 17(1), 7991. https://doi.org/10.1016/j.egypro.2012.02.078

Yin, T, -S., Yusof, Z, -M., Yaacob, C, -R., Othman, O, -R., 2010. Perfomance of the traditional pooled variance t-test against the bootstrap precedure of difference between sample means. Malaysian Journal of Mathematical Sciences. 4(1), 85-94. http://einspem. upm.edu.my/journal/fullpaper/vol4no1/6.\%20Teh\%20Sin\%20Yin.pdf

Yoon, -E., Lilien, G, -L., 1985. New industrial product performance: the effects of market characteristics and strategy. Journal of Production Inovation. 2(3), 134144. https://doi.org/10.1016/07376782(85)90033-5 